\title{
The Role of Tourism Logistics to Develop Tourist Loyalty in Rural Areas Tourism
}

\author{
Much. Djunaidi $^{1}$ *, Brillian Nur Diansari ${ }^{2}$, Ahmad Kholid Alghofari ${ }^{3}$, Hari Prasetyo ${ }^{4}$ \\ ${ }^{1}$ Universitas Muhammadiyah Surakarta, Indonesia, *Corresponding much.djunaidi@ums.ac.id \\ ${ }^{2}$ Universitas Muhammadiyah Surakarta, Indonesia, brilliannurdiansari17@ gmail.com \\ ${ }^{3}$ Universitas Muhammadiyah Surakarta, Indonesia, Ahmad.Kholid@ums.ac.id \\ ${ }^{4}$ Universitas Muhammadiyah Surakarta, Indonesia, hari.prasetyo@ums.ac.id
}

\begin{abstract}
In the last decade, tourism is a fast-growing industrial sector in Indonesia. The available natural resources become a comparative advantage that supports this growth. The development of tourism potential in rural areas with the availability of tourism logistics is expected to increase tourist satisfaction with the tourist destination. It is expected to create tourist loyalty to maintain its sustainability. This research was conducted on the development of attractions in the Ngargoyoso District, Karanganyar Regency, Central Java Province, which is a rural area in Indonesia. The study involved 150 respondents who were tourists visiting the tourist area. The analysis was performed by structural equation modelling (SEM) method. Data processing was performed using AMOS software. The results show that the availability of excellent tourism logistics can increase tourist satisfaction and can also increase tourist loyalty.
\end{abstract}

Key words: tourist logistics, tourist satisfaction, tourist loyalty, structural equation modelling, rural areas.

\section{INTRODUCTION}

In 2017, the tourism sector in Indonesia recorded the 9th highest growth in the world, according to The World Travel and Tourism Council (WTTC). In 2019, Indonesia's tourism competitiveness index ranking in the world will increase to 40th out of 140 countries. Previously, in 2017, Indonesia was ranked 42 and ranked 50 in 2015. In the Southeast Asia region, Indonesia's tourism competitiveness index was ranked fourth (Kompas, 5 Sept 2019).

Bank Indonesia (BI) states that tourism is the most active sector to boost Indonesia's foreign exchange. Resources needed for tourism development are available domestically. Indonesia has a variety of exotic and exciting tourist destinations, namely natural tourism, cultural tourism, and historical tourism. In 2018, more than 16 million foreign tourists visited Indonesia [1].
One thing that supports the development of tourism is the availability of tourism logistics in tourist destinations [2]. Tourism logistics is a discipline that studies the flow of tourism products based on the sale of tourism resources to meet the needs of tourism stakeholders. The availability of excellent tourism logistics will attract tourists to visit these tourist destinations [3].

Ngargoyoso District is a rural area that has been designated a priority area for tourism development by the Karanganyar Regency government. Ngargoyoso sub-district is located at the foot of Mount Lawu with exotic views surrounded by tea plantations and pristine natural forests. This area has a variety of tourism potentials that can be developed, ranging from natural tourism (namely the tea plantation of Kemuning village, Jumog waterfall, and Parang Ijo waterfall), cultural tourism (there are Sukuh temple and Cetho temple), and sports tourism (water tubing and Segoro Gunung paragliding) [4].

Previously, the Ngargoyoso area had not received much attention from the government and investors, compared to the Tawangmangu area. Tawangmangu is the tourism center of Karanganyar Regency with the presence of Gerojogan Sewu waterfall, as the main tourist attraction [5]. It can be seen from the number of tourist visits to the Ngargoyoso region, which is much lower compared to the number of visits to Tawangmangu.

Tourist destinations in rural areas require exceptional management because they have different characteristics from other tourist areas [6]. Rural tourist areas tend to be rarely visited by people with tourist areas that are well known to tourists. The rural tourism area is mentioned as an area that is separately identified and promoted to tourists as a place to visit, were enjoying the atmosphere and activities in it become the primary motive. Rural tourism has a high risk if not managed and developed by people who have top skills [7].

This research was conducted to examine the determination of tourism logistics that will be developed in the Ngargoyoso District area. Determination of tourism logistics is crucial in 
Much. Djunaidi et al., International Journal of Emerging Trends in Engineering Research, 8(9), September 2020, 5327 - 5334

ensuring tourist satisfaction in enjoying the attractions visited. Besides, the satisfaction felt by tourists will build tourist loyalty to the development of the Ngargoyoso tourism area.

\section{CONCEPTUAL BACKGROUND AND LITERATURE REVIEW}

\subsection{Rural Tourism}

The development of tourism potential is mostly done in various regions. Rural Area is one of the areas developed to increase rural income [8]. Rural tourism is a relatively new phenomenon that emerged in several countries [9].

Tourism developed because it has individual uniqueness. This uniqueness can be characterized by forested land, rotating grassland, and narrow river flow. It can also be because it has a rich historical and cultural heritage, such as historical sites, outdoor drama theaters, unique mountain arts, and crafts [10]. Rural tourism is usually located in remote villages, far from neighbors [11].

\subsection{Tourism Logistics}

Logistics is defined as a process that plans, organizes, and controls the physical and information flow from the source of origin at the point of final consumption to meet the desires of all interested parties. Concerning the tourism context, logistics is defined as the management of physical flows (including tourists or vehicles) and information (information related to tourism) [12].

Cooper studied various aspects that need to be considered in developing and offering tourism destinations from previous literature [13]. Various elements that have been studied are then classified into four aspects of tourism logistics. Aspects that need to be considered include attraction, accessibility, amenities, and ancillary.

Key factors needed for the development of tourism logistics include the availability of infrastructure, information systems, intelligence systems, ease of identification, and innovation [14]. The availability of these logistics will arouse the motives of tourists to visit. Various purposes for visiting tourists can be grouped into the need to perform physical activities, to relax mentally, to avoid the routine of daily life, to know or gain cultural knowledge or new places, and to gain experiences to be discussed later [15].

Tourism requires support from infrastructure systems and facilities that are designed effectively [16]. The existence of tourism infrastructure, cultural attractions, natural attractions, sports facilities, communication facilities, and also similarities in lifestyle are essential [17]. The development of an effective logistics industry depends on technological development, proper legislative frameworks, development of human resource competencies, and development of modern infrastructure [18].

For the development of tourism logistics that requires the involvement of many parties, collaboration is a process that must be carried out in all areas of business operations. The collaboration happens if two or more parties (companies) have mutually dependent business objectives. What is needed is to evaluate all the benefits and contributions of business actors [19]. Information disclosure is also responded differently by visitors, depending on the attitudes and behavior of visitors [20].

Indicators used to measure tourism logistics from the aspect of attraction are based on the beauty of the natural panorama (ATT1), the level of the calm of the location (ATT2), the level of air quality (ATT3), the level of water quality (ATT4), and the availability of entertainment facilities (ATT5).

The tourism logistic indicators based on accessibility are based on the availability of public transportation facilities (ACC1), the location of tourist sites (ACC2), the level of quality of the road to the tourist sites (ACC3), the availability of alternative paths to reach the location (ACC4) and the availability of road signs to the area (ACC5).

The tourism logistic indicators in terms of amenity are based on the availability of lodging at tourist sites (AME1), the availability of places to eat (AME2), the availability of shops to meet needs (AME3), game facilities for children and adults (AME4), availability of toilets (AME5), availability parking location (AME6), availability of religious facilities (AME7), and the existence of information service places (AME8).

The tourism logistic indicators from ancillary aspects are based on the level of comfort (ANC1), the level of security (ANC2), the level of cleanliness of facilities and location (ANC3), the promotion activities provided (ANC4), and the existence of tourism organizations (ANC5).

\subsection{Tourist Satisfaction}

Identifying critical dimensions of tourist satisfaction, tourism, and travel research practitioners can analyze the causes of tourist satisfaction or dissatisfaction sensitively and rectify them accordingly [21]. The level of satisfaction is the result of post-purchase evaluations by tourists of tourist destinations [22]. Satisfaction with a tourism destination is the extent of overall pleasure or contentment felt by the visitor, resulting in the ability of the trip experience to fulfill the visitor's desires, expectations, and needs concerning the trip [23].

Based on the description above, the level of tourist satisfaction in this study is measured based on an assessment of the perceived tourist quality (SAT1) and the suitability of the price level that must be paid (SAT2). 
Much. Djunaidi et al., International Journal of Emerging Trends in Engineering Research, 8(9), September 2020, 5327 - 5334

\subsection{Tourist Loyalty}

Customer loyalty is a critical aspect for a company because it is more expected, and cheaper to maintain the presence of consumers than attract new customers [24]. Thus, loyalty becomes a fundamental strategic component for the company. Tourist loyalty is a deep commitment with the desire to return to a tourist destination along with their willingness to recommend it to others [25] - [26].

Based on the description above, the tourist loyalty in this study is measured by the willingness to revisit (LOY1) and willingness to make recommendations (LOY2) others to visit.

\section{CONCEPTUAL FRAMEWORK AND HYPOTHESIS DEVELOPMENT}

\subsection{Conceptual Framework}

The proposed research model measures the relationship between each aspect of tourism logistics to tourist satisfaction. Each aspect of tourism logistics is seen as a different and separate factor in influencing tourist satisfaction [27]. Every aspect of tourism logistics is also seen as factors that also affect tourist loyalty [28]. Furthermore, the level of tourist satisfaction was allegedly also affecting the level of loyalty from tourists to the tourist area [26]. Considering the above, the conceptual framework of this research is illustrated in Figure 1.

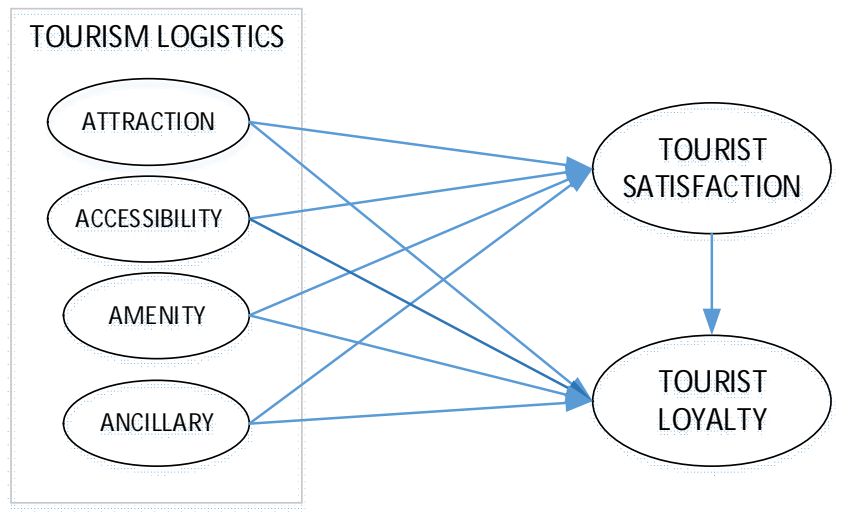

Figure 1 - The theoretical framework of the study

\subsection{Hypothesis Development}

The image developed by the manager of the tourist destination, both cognitive and affective, is intended to increase tourist satisfaction [29]. Public facilities, public infrastructure, and tourism facilities were also developed to increase tourist satisfaction [30]. Improvement of tourism logistics is mostly made to improve tourist satisfaction [18].

In the same case, the improvement of tourism facilities and infrastructure is intended to reduce the level of complaints felt by tourists. Improving the quality of tourist logistics is expected to minimize complaints [3].
The following are the hypotheses proposed based on the relationship between tourism logistics and tourist satisfaction. H1: The attraction aspect positively affects tourist satisfaction.

$\mathrm{H} 2$ : The accessibility aspect positively affects tourist satisfaction.

H3: Amenity aspect positively affects tourist satisfaction.

H4: Ancillary aspect positively affects tourist satisfaction.

Increased tourism logistics, which is an attribute of a tourist destination, is done to develop tourist loyalty. Tourism logistics was done to increase the value and expectations of tourists [31]. The availability of excellent tourism logistics plays a critical role in building tourist loyalty. By enjoying excellent tourism logistics, tourists will return to visit these tourist destinations [22].

The following are the hypotheses proposed based on the relationship between tourism logistics and tourist loyalty H5: The attraction aspect positively affects tourist loyalty. H6: The accessibility aspect positively affects tourist loyalty. H7: Amenity aspect positively affects tourist loyalty.

H8: Ancillary aspect positively affects tourist loyalty.

There is support for the impact of expectations and emotions on tourist satisfaction, which has a significant influence on intense tourist behavior [32]. Other studies emphasize other factors, such as service value and service quality, which also influence tourist loyalty [33]. Tourist loyalty is built by various aspects that shape tourist satisfaction [34].

The following is a hypothesis proposed based on the relationship between tourist satisfaction and tourist loyalty. H9: Tourist satisfaction positively affects tourist loyalty.

\section{RESEARCH METHODS}

\subsection{Sample and Data Collection}

We surveyed to collect data needed in this study. We conducted a pilot test involving 5 experts, consisting of academics, tourism object managers, government officials from the local tourism office, community leaders, and representatives of travel agents, to compile the final questionnaire, which was used as a tool to collect data.

Data collection was done by giving a final questionnaire to tourists who are visiting attractions in the Ngargoyoso region, Karanganyar. Determination of the sample of respondents is done using the Bernoulli equation, namely [35]:

$$
n=\frac{\left(z_{\alpha}\right)^{2}(p q)}{(S E)^{2}}
$$

where $\mathrm{n}$ is the minimum sample size, $\mathrm{Z} \alpha$ / 2 is the normal distribution value (1.96), $\alpha$ is the confidence level (0.05), $p$ is the proportion of the number of questionnaires that are 
Much. Djunaidi et al., International Journal of Emerging Trends in Engineering Research, 8(9), September 2020, 5327 - 5334

considered correct (0.975), $\mathrm{q}$ is the proportion of the number of questionnaires that are considered wrong (0.025), and SE is the error rate $(0.03)$. With this approach, a minimum sample size of 105 respondents is needed.

We carried out data collection in November 2019, with 150 questionnaires collected from 200 questionnaires distributed. This amount has exceeded the minimum number of samples needed, with a response rate of $75 \%$. The minimum sample size for SEM analysis with the Maximum Likelihood estimation method is 100 to 200 [36]. The number of samples has exceeded the adequacy requirements for the number of samples in the SEM analysis. The demographic composition of the respondents is shown in Table 1.

Table 1: Demographics of respondents

\begin{tabular}{cccc}
\hline \multirow{2}{*}{ Demographic } & Information & Frequency & $\begin{array}{c}\text { Percentag } \\
\mathrm{e}\end{array}$ \\
\hline \multirow{2}{*}{ Gender } & Male & 65 & $43 \%$ \\
& Female & 85 & $57 \%$ \\
\hline \multirow{3}{*}{ Age } & $15-25 \mathrm{yrs}$ & 50 & $33 \%$ \\
& $26-35 \mathrm{yrs}$ & 32 & $21 \%$ \\
& $36-45 \mathrm{yrs}$ & 40 & $27 \%$ \\
\multirow{3}{*}{ Home distance } & $>45 \mathrm{yrs}$ & 28 & $19 \%$ \\
& $<10 \mathrm{~km}$ & 33 & $22 \%$ \\
& $10-19 \mathrm{~km}$ & 31 & $21 \%$ \\
& $20-29 \mathrm{~km}$ & 23 & $15 \%$ \\
\multirow{3}{*}{ Education } & $\geq 30 \mathrm{~km}$ & 63 & $42 \%$ \\
& Elementary school & 15 & $10 \%$ \\
& Junior high school & 20 & $13 \%$ \\
& Senior high school & 74 & $49 \%$ \\
& Graduates & 41 & $27 \%$ \\
\hline
\end{tabular}

To estimate the likelihood of late response bias, we follow the procedure suggested by Moors et al. [37]. The results of t-tests suggest no difference at the 0.05 level between early and late respondents, indicating an absence of response bias. To test for common method bias, we use Harman's one-factor test. We conducted a principal component factor analysis on all the items in the study, resulting in five factors with eigenvalues above 1 (accounting for $66.7 \%$ of the total variance, with the most significant accounting for $16.1 \%$ ). Since no single factor is apparent in the un-rotated factor structure, the conventional method variance problem is not an issue in this study.

\subsection{Measurement}

Tourist logistics discusses aspects that indicate the availability of logistics in tourist destinations. Travel logistics are shown by four aspects, namely attraction (5 indicators), accessibility ( 5 indicators), amenity ( 8 indicators), and ancillary (5 indicators). We ask respondents to provide an assessment regarding the availability of logistics according to their experience while enjoying the tourist attraction, using a 5 level Likert scale assessment (value 1 indicates strongly disagree, and value 5 indicates strongly agree).
Tourist satisfaction and tourist loyalty are measured using each of the 2 indicators. We also asked respondents to provide an assessment related to their satisfaction and loyalty to a destination, using a 5 level Likert scale assessment (a value of 1 indicates very poor, and a value of 5 indicates very good).

\subsection{Measurement Validation}

Structural Equation Modelling (SEM) is a statistical analysis tool that is increasingly popular these days. When viewed from the preparation of the model and how it works, actually SEM is a combination of factor analysis and regression analysis. In the 1950s, SEM had begun to be put forward by statisticians who sought methods to create models that could explain the relationship between variables [38].

To determine composite reliability (CR) and discriminant validity, we use the confirmatory factor analysis (CFA) method. Table 3 shows the results of calculations with supporting captions that indicate the fit indices. We use CFA and do not use exploratory factor analysis (EFA) because we compile a priori theory on the relationship between item measurements and their structure. The CFA is consistent with the use of structural equation modelling (SEM) as an approach to test the model and hypothesis at the same time [39]. SEM not only provides testing of bivariate relationships between variables reviewed, but also overall causal suitability in a holistic model [40]. Shah and Goldstein provide a detailed and discipline-relevant explanation of SEM [41]. Data processing is performed using AMOS software. The results obtained from AMOS are then analyzed in the results and discussion section.

\section{RESULT AND DISCUSSION}

\subsection{Evaluation of Measurement Model}

Data collected by respondents is used to test the models developed in the conceptual framework. The first test conducted is examining the validity and reliability of indicators in each construct. In this test, all indicators are declared valid because they have a loading factor value $(\lambda)>$ 0.5 , and reliable because of the AVE value $>0.5$, and the CR value > 0.7, shown in Table 2 .

The result determines that the construct of a model for the research framework. That was compiled in the research questionnaire was acceptable to the respondents. Measurement instruments arranged in the form of questionnaires have the reliability to collect the assessment that will be given by respondents. The validity and reliability of the questionnaire are essential in quantitative research as it is being conducted [42].

The requirement for a sufficient number of samples, which is indicated by the Maximum Likelihood estimation method, is 
Much. Djunaidi et al., International Journal of Emerging Trends in Engineering Research, 8(9), September 2020, 5327 - 5334

between 100 to 200 [36]. Evaluation of normality is done by reviewing the value of $\mathrm{cr}$ skewness or kurtosis, both univariate and multivariate. Data is said to be normally distributed if the value of cr skewness or cr kurtosis is below the absolute price of 2.58 [36]. Based on Table 3, it can be said that the data collected is normally distributed.

A multicollinearity test is done by reviewing the correlation value between each exogenous variable. The model is declared free from multicollinearity if the correlation value between exogenous variables $<0.9$ [36]. The results of the analysis in Table 4 show that among the four exogenous variables (attraction, accessibility, amenity, and ancillary), there is no evidence of multicollinearity.

Table 2: Confirmatory factor analysis

\begin{tabular}{|c|c|c|c|c|c|c|}
\hline Variable & Indicators & $\lambda$ & Validity & AVE & $\mathrm{CR}$ & Reliability \\
\hline \multirow{5}{*}{$\begin{array}{l}\text { Attraction } \\
\text { (ATT) }\end{array}$} & ATT1 & 0.899 & Valid & \multirow{5}{*}{0.792} & \multirow{5}{*}{0.952} & \multirow{5}{*}{ Reliable } \\
\hline & ATT2 & 0.876 & Valid & & & \\
\hline & ATT3 & 0.895 & Valid & & & \\
\hline & ATT4 & 0.887 & Valid & & & \\
\hline & ATT5 & 0.893 & Valid & & & \\
\hline \multirow{5}{*}{$\begin{array}{l}\text { Accessibility } \\
\text { (ACC) }\end{array}$} & ACC5 & 0.868 & Valid & \multirow{5}{*}{0.796} & \multirow{5}{*}{0.952} & \multirow{5}{*}{ Reliable } \\
\hline & ACC4 & 0.898 & Valid & & & \\
\hline & $\mathrm{ACC} 3$ & 0.915 & Valid & & & \\
\hline & $\mathrm{ACC} 2$ & 0.881 & Valid & & & \\
\hline & $\mathrm{ACC} 1$ & 0.897 & Valid & & & \\
\hline \multirow{8}{*}{$\begin{array}{l}\text { Amenity } \\
\text { (AME) }\end{array}$} & AME5 & 0.887 & Valid & \multirow{8}{*}{0.760} & \multirow{8}{*}{0.980} & \multirow{8}{*}{ Reliable } \\
\hline & AME4 & 0.879 & Valid & & & \\
\hline & AME3 & 0.880 & Valid & & & \\
\hline & AME2 & 0.878 & Valid & & & \\
\hline & AME1 & 0.875 & Valid & & & \\
\hline & AME6 & 0.873 & Valid & & & \\
\hline & AME7 & 0.829 & Valid & & & \\
\hline & AME8 & 0.870 & Valid & & & \\
\hline \multirow{5}{*}{$\begin{array}{l}\text { Ancillary } \\
\text { (ANC) }\end{array}$} & ANC5 & 0.860 & Valid & \multirow{5}{*}{0.780} & \multirow{5}{*}{0.951} & \multirow{5}{*}{ Reliable } \\
\hline & ANC4 & 0.893 & Valid & & & \\
\hline & ANC3 & 0.927 & Valid & & & \\
\hline & ANC2 & 0.882 & Valid & & & \\
\hline & ANC1 & 0.853 & Valid & & & \\
\hline \multirow{2}{*}{$\begin{array}{l}\text { Satisfaction } \\
\quad(\text { SAT })\end{array}$} & SAT1 & 0.867 & Valid & \multirow{2}{*}{0.834} & \multirow{2}{*}{0.769} & \multirow{2}{*}{ Reliable } \\
\hline & SAT2 & 0.957 & Valid & & & \\
\hline \multirow{2}{*}{$\begin{array}{l}\text { Loyalty } \\
\text { (LOY) }\end{array}$} & LOY1 & 0.936 & Valid & \multirow{2}{*}{0.812} & \multirow{2}{*}{0.764} & \multirow{2}{*}{ Reliable } \\
\hline & LOY2 & 0.865 & Valid & & & \\
\hline
\end{tabular}

The significance test aims to test whether there is a significant influence of exogenous variables on endogenous variables. With a significant level of 0.05 , if the significant value $(\mathrm{P})$ $<0.05$ and c.r $>1.96$, the exogenous variable is considered to have a significant effect on endogenous variables. If the significant value $(\mathrm{P})>0.05$ and c.r $<1.96$, it is assessed that the exogenous variable has no significant effect on the endogenous variable. Table 5 shows the results of the significance tests.

The structural model compatibility test in SEM analysis is done by looking at several criteria of goodness of fit models such as Chi-Square value, probability, df, GFI, AGFI, TLI, CFI, and RMSEA. In this study, the fulfillment of the model goodness of fit will be focused on the indicator of the model goodness of fit in the form of probability values and Chi-Square models. The probability value and the chi-square model are not significant. This shows that the SEM model estimated with the analyzed data has the same covariance matrix as the population covariance matrix. Thus, the model can provide a picture of the actual condition of the population.

Table 3: Normality testing

\begin{tabular}{llllrrr}
\hline Variable & Min & Max & Skew & \multicolumn{1}{c}{ c.r. } & Kurtosis & \multicolumn{1}{c}{ c.r. } \\
\hline AME8 & 1.000 & 5.000 & -.702 & -3.509 & .213 & .533 \\
AME7 & 1.000 & 5.000 & -.492 & -2.462 & .134 & .334 \\
AME6 & 1.000 & 5.000 & -.983 & -4.913 & .710 & 1.775 \\
LOY2 & 1.000 & 5.000 & -.838 & -4.188 & .294 & .734 \\
LOY1 & 1.000 & 5.000 & -.885 & -4.426 & .328 & .820 \\
SAT2 & 1.000 & 5.000 & -.625 & -3.126 & -.055 & -.138 \\
SAT1 & 1.000 & 5.000 & -.678 & -3.388 & -.188 & -.471 \\
ANC1 & 1.000 & 5.000 & -.801 & -4.004 & .355 & .886 \\
ANC2 & 1.000 & 5.000 & -.640 & -3.198 & .074 & .186 \\
ANC3 & 1.000 & 5.000 & -.745 & -3.725 & .421 & 1.053 \\
ANC4 & 1.000 & 5.000 & -.726 & -3.628 & .397 & .993 \\
ANC5 & 1.000 & 5.000 & -.785 & -3.924 & .320 & .799 \\
AME1 & 1.000 & 5.000 & -.716 & -3.580 & .360 & .901 \\
AME2 & 1.000 & 5.000 & -.716 & -3.580 & .476 & 1.191 \\
AME3 & 1.000 & 5.000 & -.788 & -3.941 & .462 & 1.155 \\
AME4 & 1.000 & 5.000 & -.684 & -3.421 & .219 & .548 \\
AME5 & 1.000 & 5.000 & -.774 & -3.869 & .449 & 1.123 \\
ACC1 & 1.000 & 5.000 & -.510 & -2.549 & -.155 & -.387 \\
ACC2 & 1.000 & 5.000 & -.632 & -3.162 & .069 & .173 \\
ACC3 & 1.000 & 5.000 & -.760 & -3.800 & .316 & .791 \\
ACC4 & 1.000 & 5.000 & -.700 & -3.501 & .242 & .604 \\
ACC5 & 1.000 & 5.000 & -.705 & -3.527 & -.035 & -.088 \\
ATT5 & 1.000 & 5.000 & -.731 & -3.656 & .239 & .597 \\
ATT4 & 1.000 & 5.000 & -.603 & -3.013 & .276 & .690 \\
ATT3 & 1.000 & 5.000 & -.572 & -2.859 & .220 & .549 \\
ATT2 & 1.000 & 5.000 & -.536 & -2.679 & .156 & .389 \\
ATT1 & 1.000 & 5.000 & -.518 & -2.592 & -.060 & -.149 \\
\hline Multivariate & & & & & -12.922 & -2.000 \\
\hline
\end{tabular}

Table 4: Multicollinearity testing

\begin{tabular}{cccc}
\hline & & & Estimate \\
\hline ATT & $\leftarrow \rightarrow$ & ACC & .650 \\
ACC & $\leftarrow \rightarrow$ & AME & .699 \\
AME & $\leftarrow \rightarrow$ & ANC & .621 \\
ACC & $\leftarrow \rightarrow$ & ANC & .736 \\
ATT & $\leftarrow \rightarrow$ & ANC & .618 \\
ATT & $\leftarrow \rightarrow$ & AME & .687 \\
\hline
\end{tabular}

Table 5: Significance testing

\begin{tabular}{|c|c|c|c|c|c|c|c|}
\hline & & & $\begin{array}{c}\text { Estimat } \\
\mathrm{e}\end{array}$ & S.E. & C.R. & $\mathrm{P}$ & Label \\
\hline SAT & $\leftarrow$ & ATT & .206 & .103 & 1.996 & .046 & par_19 \\
\hline SAT & $\leftarrow$ & ACC & .110 & .119 & .930 & .352 & par_20 \\
\hline SAT & $\leftarrow$ & AME & .288 & .109 & 2.645 & .008 & par_21 \\
\hline SAT & $\leftarrow$ & ANC & .481 & .112 & 4.279 & $* * *$ & par_22 \\
\hline LOY & $\leftarrow$ & SAT & .390 & .121 & 3.220 & .001 & par_23 \\
\hline LOY & $\leftarrow$ & ATT & .249 & .108 & 2.315 & .021 & par_24 \\
\hline LOY & $\leftarrow$ & $\mathrm{ACC}$ & -.065 & .123 & -.530 & .596 & par_25 \\
\hline LOY & $\leftarrow$ & AME & .239 & .117 & 2.050 & .040 & par_26 \\
\hline LOY & $\leftarrow$ & ANC & .037 & .128 & .293 & .770 & par_27 \\
\hline
\end{tabular}


Much. Djunaidi et al., International Journal of Emerging Trends in Engineering Research, 8(9), September 2020, 5327 - 5334

\subsection{Discussion}

A lot of research has done the relationship between tourism logistics with the level of tourist satisfaction. In each study result, not all aspects of tourism logistics summarized are reviewed together [13]. By using the terms tourism destination attributes, tourist logistics, which include attractions, accessibility, accommodation, ancillary, and awareness, show a significant influence on tourist satisfaction [43]. Islam et al. use a variety of attributes that are aligned with tourism logistics associated with tourist satisfaction [17]. The findings in this study are aspects of attraction, amenity, and ancillary considered to have a significant influence on tourist satisfaction. The results have been proven in various previous studies [44]-[45]. The result shows that the three aspects of tourism logistics are considered to be in good condition so that it can provide satisfaction to tourists.

Accessibility is considered not to have a significant effect. This finding is, of course, inversely proportional to the various studies that have been done before. However, accessibility did not have a significant effect on several studies, such as Papuma Beach, Jember [46], shopping tourism in Bandung [47], and the historic district in Kuala Lumpur [48]. Accessibility conditions are still limited, such as there is no public transportation; there is only one access road with narrow and winding terms; it does not prevent tourists from visiting the location. The same thing also happens in the tourist attraction of Gili Ketapang [44].

The direct influence of tourism logistics on tourism loyalty has not been done much by previous researchers. Surya et al., which examines the cognitive image of attractions (including attractions, accessibility, and ancillary) and effective imagery (including life and excitement), shows a significant influence on tourism loyalty [49]. While the quality of service does not have a substantial effect on tourism loyalty [50]. This research resulted in the accessibility, and ancillary aspects have no significant effect, while the aspects of attraction and amenity show considerable influence.

There have been many studies that examine the effect of tourist satisfaction on other factors, such as tourist behavior, travel motivation, and tourism loyalty. Most studies examine the relationship between tourist satisfaction with tourism loyalty [45]. The result is a significant positive effect between tourist satisfaction and destination loyalty [50], and that applies globally [51]. Some even put tourist satisfaction as an element in tourism loyalty [52]. The results of this study confirm and confirm the previous results.

\section{Conclusion}

Based on the research results obtained, for rural tourism, attractions and amenity have a significant influence on tourist satisfaction and tourist loyalty. Ancillary aspects have a significant effect on tourist satisfaction but do not have a substantial impact on tourist loyalty. The accessibility aspect has no significant effect on tourist satisfaction and also tourist loyalty. Whereas tourist satisfaction has a significant influence on tourism loyalty.

\section{REFERENCES}

1. BPS, Jumlah Kunjungan Wisatawan Mancanegara per Bulan ke Indonesia Menurut Pintu Masuk, (Jakarta: Biro Pusat Statistik), 2019

2. Y. Tkachuk, Logistics in A Tourism Market, Thesis, Kymenlaakso University of Applied Science, Finland, 2017.

3. S. Lee, S. Jeon, D. Kim, The impact of tour quality and tourist satisfaction on tourist loyalty: The case of Chinese tourists in Korea. Tourism Management, 32, 1115-1124, 2011.

4. BPS Karanganyar, Kecamatan Ngargoyoso Dalam Angka 2018. (Karanganyar: BPS Karanganyar), 2018.

5. S. Marwanti, Pengembangan Agrowisata Berbasis Masyarakat di Kabupaten Karanganyar. Caraka Tani - Journal of Sustainable Agriculture, 30 (2), 48 55, 2015.

6. S.S. Lebe, B. Milfelner, Innovative organisation approach to sustainable tourism development in rural areas. Kybernetes, 35 (7/8), 1136 - 1146, 2006.

7. P. Schaumann, The Guide to Successful Destination Management, The Wiley Event Management Series. (Hoboken, NJ: Wiley), 2005.

8. M. Pakurar, J. Olah, Definition of Rural Tourism and Its Characteristics in the Northern Great Plain Region, Analele Universităţii din Oradea, Fascicula: Ecotoxicologie, Zootehnie şi Tehnologii de Industrie Alimentară, 7, 255-260, 2008.

9. S.M.C. Loureiro, F.J.M. Gonzalez, The importance of quality, satisfaction, trust, and image concerning rural tourist loyalty. Journal of Travel \& Tourism Marketing, 25 (2), 117-136, 2008.

10. K.-S. Chon, M.R. Evans, Tourism in a rural area - A coal mining-county experience, Tourism Management, 10 (4), 315-321, 1989

11. J. Pesonen, R. Komppula, C. Kronenberg, M. Peters, Understanding the Relationship Between Push and Pull Motivations in Rural Tourism, Tourism Review, 66 (3), 32-49, 2011.

12. T. Theppitak, Logistics Management. (Bangkok, Thailand: Expertnet Publishing), 2006.

13. C. Cooper, Tourism: Principle and Practice. 4th edition. (Harlow: Prentice Hall Financial Times), 2008.

14. P. Piboonrungroj, K. Sangkakorn, K., Tourism logistics management: A case of cultural creative tourism in Thailand, Proceedings of World Conference on Hospitality, Tourism, and Event Research 2013, Bangkok, Thailand, 2013 
Much. Djunaidi et al., International Journal of Emerging Trends in Engineering Research, 8(9), September 2020, 5327 - 5334

15. M. Mehmetoglu, O. Normann, The link between travel motives and activities in nature-based tourism. Tourism Review, 68 (2), 3 - 13, 2013

16. T. Theppitak, Managing tourism logistics with sustainable development of eco-tourism. International Journal of Advanced Scientific Research \& Development (IJASRD), 05 (08), 1-11, 2018.

17. S. Islam, M.K. Hossain, M.E. Noor, Determining drivers of destination attractiveness: The case of nature-based tourism of Bangladesh. International Journal of Marketing Studies, 9 (3), 10-20, 2017.

18. F.H.A. Pinnock, I. Ajagunna, S. Casanova, Analysis of market conditions for logistics services and tourism: a Caribbean perspective. Worldwide Hospitality and Tourism Themes, 9 (1), 4-16, 2017.

19. B. Savriña, D. Grundey, K. Bērziña, Cooperation - the form of sustainable tourism industry in Latvia. Baltic Journal of Sustainability: Technological and Economic Development, 14 (2), 151-161, 2008.

20. S. Poudel, G.P. Nyaupane, The role of interpretative tour guiding in sustainable destination management: A comparison between guided and non-guided tourists. Journal of Travel Research, 52 (5), 659-672, 2013.

21. A. Pizam, Y. Neumann, A. Reichel, Dimensions of tourist satisfaction with a destination area. Annals of Tourism Research, 5 (3), 314-322, 1978.

22. W. Chiu, S. Zeng, S., P.S-T. Cheng, The influence of destination image and tourist satisfaction on tourist loyalty: A case study of Chinese tourists in Korea. International Journal of Culture, Tourism and Hospitality Research, 10 (2), 223-234, 2016.

23. M.R. Jalilvand, J.K. Pool, L.N. Vosta, J.S. Nafchali, The effect of marketing constructs and tourists' satisfaction on loyalty to a sport destination: A structural equation model and analysis. Education, Business, and Society: Contemporary Middle Eastern Issues, 7 (4), 316-332, 2014.

24. J.F. Petrick, E. Sirakaya, Segmenting cruisers by loyalty. Annals of Tourism Research, 31 (2), 472-475, 2004.

25. A. Andreas, H.K. Tunjungsari, Pengaruh citra destinasi dan perceived value terhadap loyalitas wisatawan melalui kepuasan wisatawan. Jurnal Manajerial dan Kewirausahaan. 1 (1), 21-29, 2018.

26. L. Su, M.K. Hsu, S. Swanson, The effect of tourist relationship perception on destination loyalty at a world heritage site in China: The mediating role of overall destination satisfaction and trust. Journal of Hospitality \& Tourism Research, 41(2), 180 - 210, 2017.

27. S.M.C. Loureiro, F.J.M. Gonzalez, The importance of quality, satisfaction, trust, and image concerning rural tourist loyalty. Journal of Travel \& Tourism Marketing, 25 (2), 117-136, 2008.

28. J. Setiawan, M.R. Siregar, Loyalitas wisatawan terhadap kota Banda Aceh sebagai destinasi wisata halal indonesia dengan kepuasan wisatan sebagai mediasi. Jurnal Ilmiah Mahasiswa Ekonomi Manajemen, 3 (1), 23 - 35, 2018.

29. W. Chiu, S. Zeng, P.S-T. Cheng, The influence of destination image and tourist satisfaction on tourist loyalty: A case study of Chinese tourists in Korea. International Journal of Culture, Tourism and Hospitality Research, 10 (2), 223-234, 2016.

30. O. Susetyarini, J.M. Masjhoer, Pengukuran Tingkat Keputusan Wisatawan terhadap Fasilitas Umum, Prasarana Umum, dan Fasilitas Pariwisata di Malioboro Pascarevitalisasi Kawasan, Jurnal Kepariwisataan, 12 (1), 41 - 54, 2018.

31. H. Han, B. Meng, W. Kim, Bike-traveling as a growing phenomenon: Role of attributes, value, satisfaction, desire, and gender in developing loyalty. Tourism Management, 59, 91-103, 2018.

32. I.R. del Bosque, H.R. Martin, Tourist satisfaction: A cognitive-affective model. Annals of Tourism Research, 35 (2), 551-573, 2008.

33. H-C. Liang, Impact of Logistics Service Performance on Tourist Satisfaction and Loyalty. Doctoral Thesis. RMIT Australia, 2008.

34. C.G-Q. Chi, H. Qu, Examining the structural relationships of destination image, tourist satisfaction, and destination loyalty: An integrated approach. Tourism Management, 29, 624-636, 2008.

35. P.J. Haas, C. Konig, A bi-level Bernoulli scheme for database sampling. SIGMOD '04, Proceedings of the 2004 ACM SIGMOD International Conference on Management of Data. June 2004, 275-286, 2004

36. I. Ghozali, Model Persamaan Struktural Konsep dan Aplikasi dengan Program AMOS Ver.5.0. (Semarang: Badan Penerbit Universitas Diponegoro), 2004

37. G. Moors, N.D. Kieruj, J.K. Vermunt, The effect of labeling and numbering of response scales on the likelihood of response bias. Sociological Methodology, 44 (1), 369-399, 2014.

38. S. Santoso, Structural Equation Modelling (SEM). (Jakarta: Elex Media Komputindo), 2011.

39. H. Khudov, A. Zvonko, I. Khizhnyak, V. Shulezko, V. Khlopiachyi, V. Chepurnyi, I. Yuzova, The Synthesis of the Optimal Decision Rule for Detecting an Object in a Joint Search and Detection of Objects by the Criterion of Maximum Likelihood. Int. Journal of Emerging Trends in Engineering Research, 8 (2), 520 524, 2020.

40. N. Worren, K. Moore, P. Cardona, Modularity, strategic flexibility, and firm performance: A study of the home appliance industry. Strategic. Management Journal, 23, 1123-1140, 2002.

41. R. Shah, S.M. Goldstein, Use of structural equation modelling in operations management research: looking back and forward. Journal of Operation. Management, 24 (2), 148-169, 2006.

42. R. Heale, A. Twycross, Validity and reliability in quantitative studies. Evidence-Based Nurse, 18 (3), 66 $-67,2015$. 
43. H. Chahal, A. Devi, How perceived risk influences image and loyalty relationship in a tourist destination? An Indian perspective. International Journal of Leisure and Tourism Marketing, 5 (2), 100-127, 2017.

44. T. Ismail, F. Rohman, The role of attraction, accessibility, amenities, and ancillary on visitor satisfaction and visitor attitudinal loyalty of Gili Ketapang beach. Jurnal Manajemen Teori dan Terapan, 12 (2), 149-165, 2019

45. A. Sangpikul, The effects of travel experience dimensions on tourist satisfaction and destination loyalty: the case of an island destination. International Journal of Culture, Tourism and Hospitality Research, 12 (1), 106-123, 2018.

46. T.P. Robustin, R.A. Sularso, I. Suroso, D. Yulisetiarini, Awareness of Tourism Products and Tourist Satisfaction: A Case of Indonesia. Journal of Business and Economics Review, 3 (2), 35 - 41, 2002.

47. D. Suhartanto, R. Ruhadi, N. Triyuni, Tourist loyalty toward shopping destination: the role of shopping satisfaction and destination image. European Journal of Tourism Research, 13 (1), 84 - 102, 2016.
48. M. Mansouri, N. Ujang, Tourist' expectation and satisfaction towards pedestrian networks in the historical district of Kuala Lumpur, Malaysia. Asian Geographer, 33 (1), 35-55, 2016.

49. E.D. Surya, E.S. Rini, N. Setiawan, The Effect of Halal Destination Image and Visitors Satisfaction on Tourist Loyalty (Object in the Bukit Tinggi City of West Sumatera). Advances in Economics, Business and Management Research, 46, 558 - 564, 2017.

50. M. Mohamad, N.I. Ab Ghani, M. N. M. Nasir, The Impact of Perceived Value, Destination Service Quality, and Tourist Satisfaction on Destination Loyalty among International Tourists Visiting Malaysia. Journal of Tourism, Hospitality and Environment Management, 4 (16), 10-26, 2019.

51. C.-W. Wu, Destination loyalty modelling of the global tourism. Journal of Business Research, 69 (6), 2213-2219, 2016.

52. C. Anton, C. Camarero, M. Laguna-García, Towards a new approach of destination loyalty drivers: satisfaction, visit intensity, and tourist motivations. Current Issues in Tourism, 20 (3), 238-260, 2014 